\title{
Some Advances in Supercritical Fluid Extraction for Fuels, Bio-Materials and Purification
}

\author{
Yizhak Marcus \\ Institute of Chemistry, The Hebrew University, Jerusalem 91904, Israel; ymarcus@vms.huji.ac.il
}

Received: 21 February 2019; Accepted: 11 March 2019; Published: 13 March 2019

\begin{abstract}
Supercritical fluids are used for the extraction of desired ingredients from natural materials, but also for the removal of undesired and harmful ingredients. In this paper, the pertinent physical and chemical properties of supercritical water, methanol, ethanol, carbon dioxide, and their mixtures are provided. The methodologies used with supercritical fluid extraction are briefly dealt with. Advances in the application of supercritical extraction to fuels, the gaining of antioxidants and other useful items from biomass, the removal of undesired ingredients or contaminants, and the preparation of nanosized particles of drugs are described.
\end{abstract}

Keywords: supercritical water; supercritical methanol; supercritical ethanol; supercritical carbon dioxide; fuels; biomass; contaminant removal; drug particles

\section{Introduction}

Extraction by supercritical fluids pertains to the selective extraction of desired ingredients or removal of undesired ingredients from natural materials. The first aspect is illustrated by the gaining of hydrogen or biodiesel by supercritical water extraction of biomass on the one hand and the very large-scale application of supercritical carbon dioxide for the decaffeination of coffee on the other.

The supercritical fluids that have so far been used for the extraction purposes mentioned above include water, methanol, ethanol, and carbon dioxide, as well as their mixtures. It is necessary to know the relevant critical properties of these fluids, shown in Table 1, in order to appreciate the temperature and pressure conditions at which the supercritical fluid extractions have to be carried out. It is clear that much milder conditions are involved with the use of supercritical carbon dioxide than for the other supercritical fluids, but each fluid has its own particular advantages.

Table 1. The properties of pure water, methanol, ethanol, and carbon dioxide at the critical point.

\begin{tabular}{ccccc}
\hline Property & Water [1] & Methanol [2] & Ethanol [2] & $\mathbf{C O}_{2}$ [3] \\
\hline Critical temperature, $T_{\mathrm{c}} / \mathrm{K}$ & 647.096 & 512.6 & 514.1 & 304.18 \\
Critical temperature, $\mathrm{t}_{\mathrm{c}} /{ }^{\circ} \mathrm{C}$ & 373.95 & 239.45 & 241.0 & 31.03 \\
Critical pressure, $P_{\mathrm{c}} / \mathrm{MPa}$ & 22.064 & 8.092 & 6.137 & 7.38 \\
Critical pressure, $P_{\mathrm{c}} / \mathrm{atm}$ & 217.75 & 79.86 & 60.57 & 72.83 \\
Critical density, $\rho_{\mathrm{c}} / \mathrm{kg} \mathrm{m}^{-3}$ & 322 & 272 & 276 & 468 \\
Critical molar volume, $V_{\mathrm{c}} / \mathrm{cm}^{3} \cdot \mathrm{mol}^{-1}$ & 55.95 & 117.7 & 166.8 & 94.0 \\
Critical dynamic viscosity, $\eta_{\mathrm{C}} / \mu \mathrm{Pa} \cdot \mathrm{s}$ & 24.5 & $40^{\mathrm{a}}$ & & 29.2 \\
\hline
\end{tabular}

${ }^{\text {a }}$ Read from a small-scale figure in Reference [4].

The chemical and physicochemical properties of the supercritical fluids that are relevant to extraction are their hydrogen bond donation and acceptance abilities, and their polarity and polarizability. These properties for room temperature solvents are generally obtained by solvatochromic probes, and for the supercritical fluids they are discussed in Reference [5], 
their applicability being much diminished. Hydrogen bonding and hydrogen bond donation and acceptance persist in supercritical water, methanol, and ethanol, but are absent in supercritical carbon dioxide that is non-polar but has an appreciable quadrupole moment. The dielectric permittivity of supercritical fluids is small and diminishes with increasing temperatures, but at aiven temperature increases with the pressure, i.e., the density. Near the critical point the static permittivity $\varepsilon_{0}=8.6$ for water [1], 4.8 for methanol [6], and 1.3 for carbon dioxide [7]. The cohesive energy densities and their square roots, i.e., the total (Hildebrand) solubility parameters, as well as the partial (Hansen) solubility parameters of the supercritical fluids are shown in Table 2 as near the reduced temperature $T_{r}=T / T_{\mathrm{c}}=1.1$ and pressure $P_{r}=P / P_{\mathrm{c}}=1.1$ as data are available.

Table 2. The cohesive energy densities ced, the total solubility parameters $\delta_{\mathrm{H}}$, and the partial solubility parameters for dispersion $\delta_{\mathrm{d}}$, for polarity $\delta_{\mathrm{p}}$, and for hydrogen bonding $\delta_{\mathrm{hb}}$ of the supercritical fluids.

\begin{tabular}{ccccc}
\hline Condition and Property & Water [8] & Methanol [9] & Ethanol [10] & $\mathbf{C O}_{\mathbf{2}}$ [11] \\
\hline$T / \mathrm{K}$ & 723 & 575 & 548 & 335 \\
$T_{\mathrm{r}}$ & 1.12 & 1.12 & 1.07 & 1.10 \\
$P / \mathrm{MPa}$ & 25 & 10 & 10 & 8 \\
$P_{\mathrm{r}}$ & 1.13 & 1.24 & 1.63 & 1.08 \\
$C e d / \mathrm{MPa}$ & 21 & 18 & 46 & 30 \\
$\delta_{\mathrm{H}} / \mathrm{MPa}^{1 / 2}$ & 4.6 & 4.3 & 6.8 & 5.5 \\
$\delta_{\mathrm{d}} / \mathrm{MPa}^{1 / 2}$ & 1.0 & 1.7 & 4.4 & 5.2 \\
$\delta_{\mathrm{p}} / \mathrm{MPa}^{1 / 2}$ & 5.3 & 5.1 & 4.7 & 3.4 \\
$\delta_{\mathrm{hb}} / \mathrm{MPa}^{1 / 2}$ & 2.6 & 4.3 & 2.1 & 3.9 \\
\hline
\end{tabular}

The properties shown above pertain to the neat supercritical fluids dealt with in this review, but mixtures of these fluids are employed in many practical extraction processes. Therefore, some properties of such mixtures are also relevant for an appreciation of the advances made in this field. Thermophysical properties of mixtures of methanol and water at supercritical conditions are discussed in [12]. The critical temperatures and pressures of the mixtures depend, in a quadratic manner, on the mole fraction of the methanol:

$$
\begin{gathered}
T_{c} / \mathrm{K}=647.6-200.6 x_{\mathrm{MeOH}}+65.8 x_{\mathrm{MeOH}}{ }^{2} \\
P_{\mathrm{c}} / \mathrm{MPa}=22.06-23.58 x_{\mathrm{MeOH}}+9.34 x_{\mathrm{MeOH}}{ }^{2}
\end{gathered}
$$

A linear dependence of the critical densities and molar volumes of the mixtures on the mole fraction of the methanol is noted:

$$
\begin{gathered}
\rho_{\mathrm{c}} / \mathrm{kg} \mathrm{m}^{-3}=323.3-50.89 x_{\mathrm{MeOH}} \\
V_{\mathrm{c}} / \mathrm{cm}^{3} \mathrm{~mol}^{-3}=55.7+61.8 x_{\mathrm{MeOH}}
\end{gathered}
$$

Thermophysical properties of mixtures of ethanol and water at supercritical conditions are dealt with in Reference [13]. The critical temperatures and pressures of the mixtures depend in the following manner on the mole fraction of the ethanol $x=x_{\mathrm{EtOH}}$ :

$$
\begin{gathered}
T_{\mathrm{c}} / \mathrm{K}=647.1(1-x)+514.1 x+x(1-x)\left[129.8-49.95(1-2 x)+4.834(1-2 x)^{2}\right] \\
P_{\mathrm{c}} / \mathrm{MPa}=22.06(1-x)+6.15 x+x(1-x)\left[-17.44-7.455(1-2 x)-2.701(1-2 x)^{2}\right] \\
\rho_{\mathrm{c}} / \mathrm{kg} \mathrm{m}^{-3}=322(1-x)+276 x+x(1-x)\left[76.55+45.16(1-2 x)+115.71(1-2 x)^{2}\right]
\end{gathered}
$$

Only dilute solutions of water, methanol, and ethanol in supercritical carbon dioxide are relevant to the supercritical extraction processes, these polar co-solvents being called entrainers, since they enhance the ability of the non-polar carbon dioxide to dissolve polar solutes. The $T_{\mathrm{c}}\left(P_{\mathrm{c}}\right)$ curves of the 
loci of the critical points of several co-solvent mixtures with supercritical carbon dioxide have been reported in Reference [14]. The solubility of methanol in supercritical carbon dioxide at $323 \mathrm{~K}$ increases from $x_{\mathrm{MeOH}}=0.0235$ at $P / \mathrm{MPa}=7.50$ through 0.0311 at $P / \mathrm{MPa}=8.77$ to 0.0540 at $P / \mathrm{MPa}=9.47$ [15]. The solubility of ethanol in supercritical carbon dioxide increases from $x_{\mathrm{EtOH}}=0.0331$ at $313 \mathrm{~K}$ and $P / \mathrm{MPa}=8.13$ to 0.0891 at $373 \mathrm{~K}$ and $P / \mathrm{MPa}=10.31$ [16]. The solubility of water in supercritical carbon dioxide is very small, being $x_{\mathrm{H}_{2} \mathrm{O}}=0.00072$ at $0.39 \mathrm{~K}$ above $T_{\mathrm{c}}$ of the solvent [17], but water forms micro-emulsions at higher temperatures and pressures.

The methodology for the application of supercritical fluids has been advanced in recent years by using ultrasound and microwave assistance for the extraction process. Other techniques have been developed for obtaining the desired products from the extracts, namely rapid expansion of supercritical solvents (RESS), supercritical anti-solvents (SAS), and the gas saturated solutions method (PGSS) to produce nanoparticles of drugs for their enhanced administration and physiological availability. In these methods, the supercritical fluid is first used to extract the desired materials from natural sources and then application of these variants produces the required nano-particles. The rapid expansion of supercritical solvents (RESS) process was introduced by Matson et al. in 1987 [18], was fully described in Reference [19], and advances in the method were described in Reference [20]. The state-of-the-art supercritical anti-solvent (SAS) technique was described in Reference [21] and that of the gas saturated solutions method (PGSS) was described in Reference [22].

\section{Supercritical Extraction Applied to Fuels}

Advances in the desulfurization of coal by supercritical extraction with methanol and with ethanol have been noted. Supercritical methanol at 673 to $723 \mathrm{~K}$ removed about $45 \%$ of the organic sulfur from Canadian coal [23]. Desulfurization of low-ranking coal from Thailand appears to require the addition of potassium hydroxide to the supercritical ethanol. Up to $48 \%$ of the sulfur could be removed with $5 \mathrm{~g} \mathrm{dm}^{-3}$ of $\mathrm{KOH}$ at $623 \mathrm{~K}$ and $8.3 \mathrm{MPa}$ of supercritical ethanol [24].

The recovery of liquid fuels from coal by supercritical extraction has shown recent advances. Supercritical water for extraction of liquid products was applied to lignite coal of Turkish origin [25] and Dayan lignite coals [26]. Increasing pressure and temperatures in the range 673 to $723 \mathrm{~K}$ were effective for increasing the yield of liquid fuels, but higher temperatures enhanced mainly gas and light oil production. Supercritical water was also applied to some Chinese coals, the maximal extraction rate occurred near $670 \mathrm{~K}$ and the gas $\left(\mathrm{CO}, \mathrm{H}_{2}, \mathrm{CH}_{4}\right)$ and extract yields increased with pressure [27]. Higher temperatures of 673 to $1033 \mathrm{~K}$ and pressures of $30 \mathrm{MPa}$ were used for the supercritical extraction of brown coal from Russia, with a conversion of $48 \%$ to $63 \%$ to liquid and gaseous products [28].

Sub- and supercritical water extraction was applied to bitumen for the production of gaseous fuel, mainly hydrogen and carbon monoxide, at supercritical conditions [29]. Supercritical fluid extraction at $673 \mathrm{~K}$ with water (at 21.2-24.7 MPa), methanol (at 8.6 MPa), and ethanol (at 11.9 MPa), among other solvents, was applied to bituminous Illinois No. 6 coal, but the conversion yield to liquid and gaseous fuels with the water (34\% and 39\%) was larger than with methanol $(8.4 \%)$ and ethanol (17.5\%) [30]. Sensitivity to the pressure applied was noted for extraction with supercritical ethanol at $673 \mathrm{~K}$; at $20.5 \mathrm{MPa}$ it yielded a $35.7 \%$ conversion to liquid products, but only $78.6 \%$ ethanol recovery. At the expense of a much lower conversion to liquid products of $22.2 \%$ [31], the recovery was increased to $84.3 \%$ by lowering the pressure at $673 \mathrm{~K}$ to $12.7 \mathrm{MPa}$. Extraction by supercritical methanol and ethanol (also propanols, butanols, and pentanols) was applied to Brazilian coals with a recovery of $>40 \%$ of liquid and gaseous products [32]. Pure ethanol as well as its aqueous mixtures (also isopropanol) were applied as supercritical fluids at 598-698 K and $\leq 12.5 \mathrm{MPa}$ to high-ash Brazilian coal, for which increased temperatures and pressures increased the conversion yield [33]. Supercritical extraction with methanol and ethanol was applied to high-volatile bituminous coal from the Saar region in Germany and the dependence of the extraction yields on the conditions employed was studied [34]. Supercritical water with admixture in a 1:1 mass ratio of methanol and more so ethanol increased the yield of liquid products from coal significantly (at $623 \mathrm{~K}$ ) [35]. 
Supercritical fluids also treated another kind of material, namely oil shales, in order to obtain liquid (eventually also gaseous) fuels. Extraction with supercritical methanol and its mixtures with water at $473 \mathrm{~K}$ of Green River oil shale showed that esterification products were responsible for a part of the methanol being consumed, but the process produced liquid organic materials beyond these products [36]. Some $90 \%$ of the organic material in the shale were obtained on extraction at $673 \mathrm{~K}$ with a $50 \mathrm{vol} . \%$ mixture of water and methanol for $34 \mathrm{~min}$ [37]. Chinese Maoming oil shales at $673 \mathrm{~K}$ were subjected to supercritical water with $45 \%$ oil recovery when heated at this temperature for $1 \mathrm{~h}$ [38]. When supercritical water was applied at a lower temperature, $648 \mathrm{~K}$ (just critical) to extract oil from Turkish oil shale, the yield was $75 \%$ after $1 \mathrm{~h}$ treatment [39]. Turkish (Beypazari) oil shales were extracted with supercritical water up to $698 \mathrm{~K}$, the asphaltene fraction diminished but the polar fraction of the produced oil increased in this temperature range [40]. Moroccan oil shales treated by supercritical water at 653 to $673 \mathrm{~K}$ yielded oils with increasing yields and diminishing fractions of asphaltenes [41]. Retorting and supercritical extraction with water at $712 \mathrm{~K}$ and $24.9 \mathrm{MPa}$ of Jordanian (El-Lajjun) oil shales produced the highest oil yield at nearly $47 \%$ [42]. Russian oil shales (Bazhenov formation) were treated with supercritical water up to $753 \mathrm{~K}$ and liquid products were recovered at $673 \mathrm{~K}$ and $30 \mathrm{MPa}$, whereas at the highest temperature secondary hydrocarbon formation was observed [43]. The yield of liquid products from Russian (Krassava) and Bulgarian (Syssola) oil shales increased from 18 to 37 and $44 \%$ for the Russian shale, but less, from 13 to 18 and $35 \%$, for the Bulgarian shale on admixture in a 1:1 mass ratio of methanol and more so ethanol to supercritical water (at $623 \mathrm{~K}$ ) [35].

\section{Supercritical Fluid Extraction from Bio-Materials}

Recently, extraction with supercritical water, methanol, and ethanol of solutes from biomaterials has been extensively reported. However, the term 'supercritical fluid extraction' in the literature does generally pertain to extraction with supercritical carbon dioxide, possibly with modifiers, such as methanol and ethanol.

Extraction with supercritical water, methanol, and ethanol has been applied to cellulosic materials, including lignin. Treatment of Japanese Sugi wood (Cryptomeria japonica) with supercritical water resulted in various products that could be identified in the water-soluble, methanol-soluble, and methanol-insoluble fractions [44]. Japanese beech (Fagus crenata Blume) was treated with supercritical methanol containing some water, and a $10 \mathrm{vol} \%$ water at $623 \mathrm{~K}$ was found to be optimal, for obtaining products from the lignocelluloses [45]. Supercritical water at $653 \mathrm{~K}$ and $100 \mathrm{MPa}$ was applied to Japanese beech as well as oil palm trunks to obtain low molecular size products [46]. German beech wood was treated with supercritical ethanol, optimally at $589 \mathrm{~K}$, to produce bio-oil [47]. Pre-treatment by water at 453 to $623 \mathrm{~K}$ of holm oak was used to hydrolyze hemicellulose, and then supercritical water at $669 \mathrm{~K}$ at $24.5 \mathrm{MPa}$ was used for extraction of low molecular mass products, e.g., lactic acid [48].

Cellulosic and lignin materials that were not of wood origin have also been subjected to supercritical fluid extraction in recent years. Bagasse of sugar cane stalks was treated by supercritical ethanol at $603 \mathrm{~K}$ to yield bio-oil [49]. Wet biomass (olive husk, cotton cocoon shell, and tea waste) can be dealt with directly by supercritical water without need of drying, to produce hydrogen and methane beside carbon oxides. The yields increase with temperature in the range 650 to $700 \mathrm{~K}$ and with pressure in the range 23 to $38 \mathrm{MPa}$ [50]. The hydrolysis, fractionation, and extraction of biomass containing cellulose, hemicellulose, and lignin by supercritical water at $673 \mathrm{~K}$ was dealt with in two recent reviews [51,52]. The yields of phenolics, for example, increase with increasing density (pressure) and temperature of the supercritical water.

Extraction with supercritical carbon dioxide has been applied to non-wood cellulosic plant materials, such as leaves, roots, fruits, seeds, and pomace. Flavonoids have been extracted with supercritical carbon dioxide from Scutellaria baicalensis roots [53] and from Maydis stigma (from maize flowers) [54], and flavonoids as well as ginkgolides were extracted likewise from Ginkgo leaves [55]. Carotenoids were extracted with supercritical carbon dioxide from carrots with canola oil 
as a co-solvent [56], from pitanga fruits (Eugenia uniflora L.) [57], and together with tocopherols and sitosterols from industrial tomato by-products [58]. Seeds of black sesame (Sesamum indicum L.) [59] and of fenugreek (Trigonella foenum-graecum L.) [60] were subjected to supercritical carbon dioxide extraction to obtain phytosterols and other bioactive ingredients. Peels of Citrus Unshiu were subjected to supercritical carbon dioxide extraction with an ethanol co-solvent entrainer to obtain nobiletin (a polymethoxyflavone) [61]. Carob biomass (Ceratonia silique L.) was extracted by supercritical carbon dioxide assisted by ultrasound to obtain phenolic antioxidants [62], which were also obtained by this technique from Rumex acetosa L. roots [63]. Extracts of Polish blackberry (Rubus fruticosus) pomace by supercritical carbon dioxide contained omega fatty acids, phytosterols, and tocopherols, and showed antioxidant activities [64]. Selective retrieval of phenolic compounds from guarana (Paullinia cupana) seeds was achieved by supercritical carbon dioxide extraction in Reference [65]. Algerian Rosmarinus eriocalyx was submitted to supercritical carbon dioxide extraction to obtain its antioxidant components [66]. Monocrotaline was extracted from Crotalaria spectabilis seeds by means of supercritical carbon dioxide with an ethanol co-solvent and the process was modelled in Reference [67].

Biodiesel, i.e., liquid fuel from biomass, and gaseous fuel were obtained from plant materials by supercritical fluid extraction with water, methanol, ethanol, and their mixtures. Supercritical water at 650 to $750 \mathrm{~K}$ and 23 to $48 \mathrm{MPa}$ was used to produce hydrogen-rich gas from almond, hazelnut, walnut, sunflower shells, and cotton cocoon as wet biomass [68]. Supercritical fluid extraction with methanol and ethanol (also acetone and 2-butanol) was applied to bulrush plants, Typha latifolia, for liquefaction at 518 to $558 \mathrm{~K}$ [69]. Liquefaction to produce bio-oils by means of supercritical methanol or ethanol (also acetone) at 523 to $563 \mathrm{~K}$ was applied to thistle stalks, Onopordum heteracanthum [70]. Supercritical water at $923 \mathrm{~K}$ and $25 \mathrm{MPa}$ was used for the gasification of glucose to produce hydrogen [71]. Flax seeds were subjected to supercritical ethanol extraction at $606 \mathrm{~K}$ for the production of bio-oils, consisting mainly of fatty acid esters [72].

Useful products were recovered from marine plants and algae when treated with supercritical fluids. Supercritical methanol at $528 \mathrm{~K}$ yields biodiesel from wet algae [73] and direct transesterification of algal biomass under supercritical methanol at $533 \mathrm{~K}$ and microwave irradiation was comparatively successful [74]. Supercritical ethanol yielded ethyl esters when wet algae are treated by it at $533 \mathrm{~K}$ and microwave irradiation [75]. Gasification of Nannochloropsis gaditana microalgae, producing mainly hydrogen, methane, and carbon dioxide, was affected by supercritical water at $24 \mathrm{MPa}$ and $936 \mathrm{~K} \mathrm{[76].}$ The same microalgae as wet biomass were first subjected to hydrothermal liquefaction with subcritical water at $623 \mathrm{~K}$ and subsequently to extraction with supercritical water at $673 \mathrm{~K}$ in the presence of hydrogen gas to produce water-soluble biocrudes [77]. Supercritical carbon dioxide extraction of the microalgae Nannochloropsis oculata was used for the production of fatty acid methyl esters [78]. Brown seaweeds: Saccharina japonica and Sargassum horneri, are useful sources for oils extracted by supercritical carbon dioxide with ethanol co-solvent. One of the components of the extracted oils, fucoxanthin, has high anti-oxidant properties [79]. Colombian seaweeds (Gracilara mammillaris) were extracted by supercritical carbon dioxide to obtain antioxidant bioactive substances [80].

\section{Removal of Undesired Ingredients or Contaminants}

The application of supercritical fluid extraction in the food industry is mainly by the use of supercritical carbon dioxide for the removal of undesired ingredients from food. The most widely known application is the decaffeination of coffee with supercritical carbon dioxide, this subject being most recently treated in Reference [81]. Less well known is the decaffeination of tea: green tea (Camellia sinensis) leaves contain many volatile components: various alcohols, terpenes, carbonyls, and nitrogen-containing compounds. On decaffeination with supercritical carbon dioxide the contents of these components are diminished along with that of the caffeine, which is detrimental to the taste and aroma of the tea beverage prepared from the leaves [82]. Near optimal conditions for the decaffeination of green tea leaves were determined in Reference [83]: supercritical carbon dioxide at $63{ }^{\circ} \mathrm{C}$ and $23 \mathrm{MPa}$ with $3 \%$ ethanol co-solvent for $2 \mathrm{~h}$, the caffeine yield being $96.6 \%$, whereas that of 
catechins (chlorophyll) removed being only $41 \%$. Slightly more efficient for the decaffeination was a $7 \%$ ethanol content in the supercritical carbon dioxide at $70{ }^{\circ} \mathrm{C}$ and $30 \mathrm{MPa}$, where $97.4 \%$ of the caffeine was removed and only $38 \%$ of the catechins [84]. A process has been described, in which a powder of green tea leaves of particle sizes of 0.2 to $0.6 \mathrm{~mm}$ is treated with supercritical carbon dioxide containing $1 \%$ ethanol co-solvent at $80{ }^{\circ} \mathrm{C}$ and $30 \mathrm{MPa}$ for $2 \mathrm{~h}$. In this process $70 \%$ of the caffeine is removed whereas only $6 \%$ of the catechines are removed from the leaves, the remainder conferring on them a desirable taste [85].

Black tea leaves (the more oxidized variety of Camellia sinensis leaves) have also been the subject of decaffeination with supercritical carbon dioxide with somewhat wet ethanol $\left(12.5 \%\right.$ water) at $53{ }^{\circ} \mathrm{C}$ and $30 \mathrm{MPa}$. It was optimal, $99.8 \%$ of the caffeine but only $3.3 \%$ of the phenolics having been removed [86]. Lower pressure extraction conditions, namely $60{ }^{\circ} \mathrm{C}$ and $9 \mathrm{MPa}$, were recommended for maximal decaffeination but better retention of theaflavins, thearubigins, and catechins [87]. Practically $100 \%$ of the caffeine was removed by supercritical carbon dioxide containing $2.5 \%$ or $5 \%$ ethanol at $62.5{ }^{\circ} \mathrm{C}$ and 37.5 MPa in a more recent study [88].

The decaffeination with supercritical carbon dioxide of some other beverage ingredients has also been studied, for instant of cocoa powder [89]. Conditions were sought for effective caffeine removal $(80 \%)$ but retention of the polyphenolic $(85 \%)$ and theobromine $(94 \%)$ ingredients conferring antioxidant properties. The best conditions were $45 \%$ water as the co-solvent (wetting the cocoa powder) and extraction at $70{ }^{\circ} \mathrm{C}$ and $30 \mathrm{MPa}$.

An important application of supercritical carbon dioxide is the sterilization and virus inactivation of contaminated raw materials of the food industry and of its products. Such a treatment can replace thermal pasteurization detrimental to heat-sensitive products. The review by Perrut [90] describes one technique that had been employed for this purpose: Rapid pressurization/depressurization enhanced by pretreatment by a pulse of electric field. This procedure causes cell membrane rupture in bacilli, e.g., Escherichia coli and Staphylococcus aureus. The effect of pressure cycling on the inactivation of Escherichia coli by supercritical carbon dioxide was further studied in Reference [91]. Spores are resistant to this treatment, however, Penicillium oxalicum spores could be eliminated from contaminated wheat grains by inclusion of water in the supercritical carbon dioxide [92]. A similar effect is obtained with water-modified supercritical carbon dioxide applied to fungal spore contaminated barley seeds [93]. A stronger co-solvent effect on microbial inactivation than that of water is obtained by the oxidizing power of peracetic acid, a treatment applied for the storage at ambient temperatures of shredded mozzarella-type cheese [94]. Sterilization of oil palm fruits for palm oil production with supercritical carbon dioxide dispensed with steam sterilization $[95,96]$.

Supercritical water has been applied for the removal of toxic ingredients from industrial materials and from contaminated soils, with concomitant total oxidation to innocuous gases (the SCWO process). An example is the treatment of transformer oil contaminated with polychlorinated biphenyls (PCBs) in South America [97]. In this study $99.6 \%$ conversion of the total organic carbon (TOC) and reduction of the PCB level to below detection limit was achieved at $540{ }^{\circ} \mathrm{C}$ and $24 \mathrm{MPa}$ with hydrogen peroxide as the oxidant. In the Korean study [98], oil samples were emulsified in water forming the feed for the supercritical water and oxygen-enriched air was used as the oxidant. The optimal temperature and pressure were $500{ }^{\circ} \mathrm{C}$ and $26.4 \mathrm{MPa}$, the destroying efficiency was $>99.9 \%$ of the TOC and the measured dioxin in the environment of the plant was less than $15 \%$ of the Korean allowed limit.

The treatment and remediation of soils contaminated with PCBs and polycyclic aromatic hydrocarbons (PAHs) by SCWO processes is the subject of a large number of reports in the last decade. The treatment of PAH-contaminated soil from a decommissioned Swedish mine with supercritical water extraction coupled with SCWO was studied in Reference [99], resulting in 91\% PAH destruction. In a subsequent paper [100], the authors achieved a considerably better destruction of the PAHs than initially reported, namely $97.0 \%$ to $99.9 \%$, depending on the compound. Another two-stage remediation process for PCB-contaminated soils and sediments [101] involves extraction with supercritical carbon dioxide modified by methanol and subsequent SCWO treatment. The first stage operates at $50{ }^{\circ} \mathrm{C}$ and 
$12 \mathrm{MPa}$ with $5 \mathrm{~mol} \%$ methanol and the second stage operates at $500{ }^{\circ} \mathrm{C}$ and $25 \mathrm{MPa}$. SCWO treatment of contaminated soils and sediments was compared in Reference [102] with other available methods in terms of removal efficiency and costs and was found to be competitive.

\section{Preparation of Nano-Sized Particles}

Several processes through which drugs could be prepared for ready administration in the form of submicron particles by employing supercritical carbon dioxide have been reviewed [103]. These processes included the supercritical anti-solvent (SAS), the gas anti-solvent (GAS) or precipitation with compressed anti-solvent (PCA) methods, as well as particle formation using the rapid expansion of supercritical solvents (RESS) method. Even 15 years later, the use of supercritical solvents in general, and supercritical carbon dioxide in particular, in the pharmaceutical industry was still called 'nascent' and not deemed to be mature [104]. A further method for making drugs ready for administration that was described was encapsulation in host materials, such as chitosan or synthetic polymers. More recently, the importance of the particle sizes of the active pharmaceutical ingredient in a drug has been reviewed in Reference [105], where the production of micro- and nanoparticles by the RESS, SAS, and other techniques is described.

The supercritical anti-solvent process (SAS) for the precipitation of amoxicillin, the system investigated being carbon dioxide $+N$-methylpyrrolidone, is described in Reference [106]. The particle size (submicron) and particle size distribution of the precipitated amoxicillin were the criteria used for the selection of the optimal pressure and composition conditions. These criteria were also emphasized in the review [107] of the SAS, because they determine the rate of dissolution of poorly soluble drugs in aqueous bio-fluids, hence their bioavailability. Ampicillin and amoxicillin are the antibiotics specifically treated in this study, again with $N$-methylpyrrolidone solvent. Microparticles of glycyrrhizic acid (the active ingredient of licorice) were produced by the supercritical anti-solvent process (ethanol solvent and carbon dioxide anti-solvent) [108]. These particles showed enhanced dissolution in aqueous biofluids compared to the original drug.

The rapid expansion of the supercritical solutions (RESS) method has been used for the formation of bio-erodible polymeric (polylactic or polyglycolic acid) microparticles for the controlled delivery of drugs. A modification of the RESS method, consisting of expansion into a liquid solvent rather than into vacuum or air, ensures the production of nanoparticles [109]. Expansion of a solution of indomethacin in supercritical carbon dioxide into water produced submicron particles of this drug [110]. The solubility of phenytoin in pure supercritical carbon dioxide is too small for effective application of the RESS process for the production of nanoparticles of this drug. However, saturation of the supercritical carbon dioxide with menthol co-solvent (added as a solid, saturation mole fraction is 0.147 at $45^{\circ} \mathrm{C}$ ) solves this problem satisfactorily [111]. Naproxen is sufficiently soluble in supercritical carbon dioxide for the application of the RESS process, and it was found that expansion into an aqueous medium produces submicron particles that show improved dissolution behavior compared with the original material [112], with similar results also for ibuprofen.

Controlled drug delivery has been effectively provided by co-crystallization with other ingredients by the use of supercritical carbon dioxide. Co-crystallization with carboxylic acid amides or pyridine carboxylates is effective for making drugs more readily bio-available. This method, using supercritical carbon dioxide and the RESS and SAS processes has been reviewed in Reference [113]. An instance is the use of nicotinamide with the anti-inflammatory drug diflunisal in a 2:1 proportion, the drug thus precipitated from the ethanol solutions by supercritical carbon dioxide as the anti-solvent has an enhanced dissolution rate compared with pure diflunisal.

Controlled drug delivery has also been effectively provided by incorporation of the drugs in polymeric matrices produced in supercritical carbon dioxide. Polylactic acid microparticles have also been produced by the RESS process from supercritical carbon dioxide [114] for the incorporation of phytosterol. Co-polymers of polylactic and polyglycolic acids as microparticles incorporating indomethacin have been produced by a variant of the SAS method, namely, solution-enhanced 
dispersion by supercritical fluids (SEDS) [115]. This polymeric matrix, incorporating the antitumor agent 5-fluorouracil, was produced by an SAS method from supercritical carbon dioxide too [116]. Low-cross-linked polymethacrylate matrices, produced from 2-(dimethyl-amino)ethyl methacrylate and incorporating ibuprofen, were produced in supercritical carbon dioxide and shown to have high loading of the drug and efficient controlled release [117]. Soft contact lenses (Hilafilcon B) were impregnated with the drug flurbiprofen in supercritical carbon dioxide for effective release of the drug [118]. A more detailed exposition of the method was subsequently reported by these authors [119]. A solid lipid matrix consisting of a mixture of hydrogenated castor oil and glyceryl monostearate has been imprinted with ketoprofen in supercritical carbon dioxide solvent, permitting the controlled release of the drug [120].

The advantages of using supercritical carbon dioxide for the production of controlled-release polymer drug composites were summarized in Reference [121], where the challenges remaining in the application of this method were also addressed. The application of supercritical carbon dioxide to the preparation of finely divided powders of macromolecular drugs, such as proteins, genes, and insulin, for inhalation is reviewed in Reference [122].

\section{Conclusions}

The application of supercritical fluid extraction with supercritical carbon dioxide was introduced for the decaffeination of coffee beans by Zosel in 1974 [123]. This process has matured since then to a major industrial process, but advances in supercritical fluid extraction have been extensive in recent years. Supercritical water, methanol, ethanol, and their mixtures have been added to the use of supercritical carbon dioxide as extracting agents. The engineering aspects of the use of high temperatures (except in the case of carbon dioxide) and pressures have been satisfactorily dealt with, so that supercritical fluid extraction has become a mature and readily controlled process. The supercritical solvents are 'green' in that they have no detrimental effects on the environment. The selectivity of supercritical fluid extraction, being tunable by the temperature and pressure employed as well as added entrainers, is used for the solubilization of the desired solutes in a matrix, as the solvating power, driven by the density, can be altered over a wide range. Compared to traditional organic liquids, the supercritical fluids have higher diffusivity and lower viscosity, providing a significantly improved mass transfer of solutes. Applications in food, cosmetic, pharmaceuticals, agriculture, and dairy industries and at pilot scale upgraded to the industrial set up are dealt with in Reference [124]. Recent applications of supercritical fluid extraction include: gaining of bio-diesel fuels, antioxidants, and other useful items from biomass, removal of undesired ingredients or contaminants, and the preparation of nanosized particles of drugs, showing that further developments of supercritical fluid extraction are to be expected. Vitamin E in polycaprolactone nanoparticles was continuously produced by supercritical fluid extraction of emulsions using a high-pressure packing column in countercurrent mode [125]. Applications of seaweed hydrocolloids as thickeners, stabilizers, coagulants, and salves in the food, pharmaceutical, and biotechnology industries produced by neoteric extraction methods, such as supercritical fluid extraction, are highlighted in Reference [126].

Funding: This research received no external funding.

Conflicts of Interest: The authors declare no conflict of interest.

\section{References}

1. Marcus, Y. Supercritical Water; Wiley: New York, NY, USA, 2012.

2. Teja, A.S.; Lee, B.J.; Rosenthal, D.; Anselme, M. Correlation of the critical properties of alkanes and alkanols. Fluid Phase Equil. 1990, 56, 153-169. [CrossRef]

3. Marcus, Y. Supercritical Carbon Dioxide; Nova Science Publishers: New York, NY, USA, 2019. 
4. Chen, E.; Wang, C.; Ying, W.; Wang, W.; Wu, Y.; Zhang, J. Continuous production of biodiesel via supercritical methanol transesterification in a tubular reactor. Part 1: Thermophysical properties and transitive properties of supercritical methanol. Energy Fuels 2009, 23, 526-532. [CrossRef]

5. Marcus, Y. Solvatochromic probes in supercritical fluids. J. Phys. Org. Chem. 2005, 16, 373-384. [CrossRef]

6. Hiejima, Y.; Kajihara, Y.; Kohno, H.; Yao, M. Dielectric relaxation measurements on methanol up to the supercritical region. J. Phys. Condensed Matter 2001, 13, 10307-10320. [CrossRef]

7. Drake, B.D.; Smith, R.L., Jr. Measurement of static dielectric constants of supercritical fluids and cosolvents: Carbon dioxide and argon, carbon dioxide, and methanol at $323 \mathrm{~K}$ and pressures up to 25 MPa. J. Supercrit. Fluids 1990, 2, 163-168. [CrossRef]

8. Marcus, Y. Hansen solubility parameters for supercritical water. J. Supercrit. Fluids 2012, 62, 60-64. [CrossRef]

9. Marcus, Y. Total and partial solubility parameters for supercritical methanol. J. Supercrit. Fluids 2016, 111, 43-46. [CrossRef]

10. Marcus, Y. Total and partial solubility parameters of sub- and supercritical ethanol. J. Chem. Thermodyn. 2018, 126, 187-189. [CrossRef]

11. Marcus, Y. Solubility parameter of carbon dioxide-An enigma. ACS Omega 2018, 3, 524-528. [CrossRef]

12. Marcus, Y. Some thermophysical properties of methanol and aqueous methanol mixtures at sub- and supercritical conditions. J. Mol. Liq. 2017, 239, 10-13. [CrossRef]

13. Bazaev, A.R.; Abdulagatov, I.M.; Bazaev, E.A.; Abdurashidova, A. $(p, v, T, x)$ measurement of $\left\{(1-x) \mathrm{H}_{2} \mathrm{O}\right.$ $\left.+x \mathrm{C}_{2} \mathrm{H}_{5} \mathrm{OH}\right\}$ mixtures in the near-critical and supercritical regions. J. Chem. Thermodyn. 2007, 39, 385-411. [CrossRef]

14. Ziegler, J.W.; Dorsey, J.G. Estimation of liquid-vapor critical loci for $\mathrm{CO}_{2}$-solvent mixtures using a peak-shape method. Anal. Chem. 1995, 67, 456-462. [CrossRef] [PubMed]

15. Brunner, E.; Hültenschmidt, W.; Schlichhärle, G. Fluid mixtures at high pressures I. Isothermal phase equilibria in binary mixtures consisting of (methanol + hydrogen or nitrogen or methane or carbon monoxide or carbon dioxide). J. Chem. Thermodyn. 1987, 19, 273-291. [CrossRef]

16. Galicia-Luna, L.A.; Ortega-Rodriguez, A.; Richon, D. New apparatus for the fast determination of high pressure vapor-liquid equilibria of mixtures and accurate critical pressures. J. Chem. Eng. Data 2000, 45, 265-271. [CrossRef]

17. Morrison, G. Effect of water upon the critical points of carbon dioxide and ethane. J. Phys. Chem. 1981, 85, 759-761. [CrossRef]

18. Matson, D.W.; Fulton, J.L.; Petersen, R.C.; Smith, R.D. Rapid expansion of supercritical fluid solutions: Solute formation of powders, thin films, and fibers. Ind. Eng. Chem. Res. 1987, 26, 2298-2306. [CrossRef]

19. Debenedetti, P.G.; Tom, J.W.; Kwauk, X.; Yeo, S.-D. Rapid expansion of supercritical solutions (RESS): Fundamentals and applications. Fluid Phase Equil. 1993, 82, 311-321. [CrossRef]

20. Zablini, F. Mathematical equations applicability for data interpretation of pharmaceutics nano sizing by rapid expansion of supercritical solvent process. Res. J. Appl. Sci. Eng. Technol. 2013, 5, 3481-3488.

21. Villalva, M.; Jaime, L.; Villanueva-Bermejo, D.; Lara, B.; Fornari, T.; Reglero, G.; Santoyo, S. Supercritical anti-solvent fractionation for improving antioxidant and anti-inflammatory activities of an Achillea millefolium L. extract. Food Res. Internat. 2019, 115, 128-134. [CrossRef] [PubMed]

22. Melgosa, R.; Benito-Román, Ó.; Sanz, M.T.; de Paz, E.; Beltrán, S. Omega-3 encapsulation by PGSS-drying and conventional drying methods. Particle characterization and oxidative stability. Food Chem. 2019, 270, 138-148. [CrossRef] [PubMed]

23. Meffe, S.; Perkson, A.; Trass, O. Coal benefication and organic sulfur removal. Fuel 1996, 75, 25-30. [CrossRef]

24. Charutawai, K.; Ngamprasertsith, S.; Prasassarakich, P. Supercritical desulfurization of low rank coal with ethanol/KOH. Fuel Proc. Technol. 2003, 84, 207-216. [CrossRef]

25. Canel, M.; Missal, P. Extraction of solid fuels with sub- and supercritical water. Fuel 1994, 73, 1776-1780. [CrossRef]

26. Hu, H.; Guo, S.; Hedden, K. Extraction of lignite with water in sub- and supercritical states. Fuel Proc. Technol. 1998, 53, 269-277. [CrossRef]

27. Wu, B.; Hu, H.; Huang, S.; Fang, Y.; Li, X.; Meng, M. Extraction of weakly reductive and reductive coals with sub- and supercritical water. Energy Fuels 2008, 22, 3944-3948. [CrossRef] 
28. Vostrikov, A.A.; Fednaeva, O.N.; Dubov, D.Y.; Psarov, S.A.; Sokol, M.Y. Conversion of brown coal in supercritical water without and with addition of oxygen at continuous supply of coal-water slurry. Energy 2011, 36, 1948-1955. [CrossRef]

29. Park, J.H.; Son, S.H. Extraction of bitumen with sub- and supercritical water. Korean J. Chem. Eng. 2011, 28, 455-460. [CrossRef]

30. Vasilakos, N.P.; Dobbs, J.M.; Parisi, A.S. Solvent effects in supercritical extraction of coal. Ind. Eng. Chem. Proc. Des. Dev. 1985, 24, 124-128. [CrossRef]

31. Amestica, L.A.; Wolf, E.E. Supercritical toluene and ethanol extraction of Illinois No. 6 coal. Fuel 1984, 63, 227-231. [CrossRef]

32. Lanças, F.M.; Pereira, D.M. Supercritical fluid extraction of Brazilian coal with alcohols. Energy Sources 1999, 21,355-365.

33. Dariva, C.; de Oliveira, J.V.; Vale, M.G.R.; Caramao, E.B. Supercritical fluid extraction of a high-ash Brazilian coal. Fuel 1997, 76, 585-591. [CrossRef]

34. Goetz, G.; Hammer, H.; Wolf, M. Supercritical fluid extraction of high volatile bituminous coals from the Saar region, Germany. Influence of extraction parameters on extract yield and composition. Coal Sci. Technol. 1995, 24, 1403-1406.

35. Luik, H.; Luik, L. Extraction of fossil fuels with sub- and supercritical water. Energy Sources 2001, 23, 449-459. [CrossRef]

36. Shing, S.-L.; McKay, J.F. Interaction of supercritical methanol and water with organic material in Green River oil shale. Fuel Sci. Technol. Int. 1987, 5, 513-541.

37. McKay, F.F.; Blanche, M.S. Effect of time and pressure on recovery of oil from Green River oil shale in extraction experiments. Fuel Sci. Technol. Int. 1986, 4, 413-431. [CrossRef]

38. Funazukuri, T.; Yokoi, S.; Wakao, N. Supercritical fluid extraction of Chinese Maoming oil shale with water and toluene. Fuel 1988, 67, 10-16. [CrossRef]

39. Yanik, J.; Yüksel, M.; Sağlam, M.; Olukçu, M.; Bartle, K.; Frere, B. Characterization of the oil fractions of shale oil obtained by pyrolysis and supercritical water extraction. Fuel 1995, 74, 46-52. [CrossRef]

40. Olukçu, M.; Yanik, J.; Sağlam, M.; Yüksel, M. Solvent effect on the extraction of Beypazari oil shale. Energy Fuels 1999, 13, 895-902. [CrossRef]

41. El Harfi, K.; Bennouna, C.; Mokhlisse, A.; Ben Chanaa, M.; Lemèe, L.; Joffre, J.; Ambles, A. Supercritical fluid extraction of Moroccan (Timahdit) oil shale with water. J. Anal. Appl. Pyrolysis 1999, 50, 163-174. [CrossRef]

42. Tucker, J.D.; Masri, B.; Lee, S. A comparison of retorting and supercritical extraction on El-Lajjun oil shale. Energy Sources 2000, 22, 453-463.

43. Popov, E.; Kalmykov, A.; Cheremisin, A.; Bychkov, A.; Bondarenkoi, T.; Morozov, N.; Karpov, I. Laboratory investigation of hydrous pyrolysis as ternary enhanced oil recovery method for Bazhenov formation. J. Petrol. Sci. Eng. 2017, 156, 852-857. [CrossRef]

44. Takada, D.; Ehara, K.; Saka, S. Gas chromatographic and mass spectrometric (GC-MS) analysis of lignin-derived products from Cryptomeria japonica treated in supercritical water. J. Wood Sci. 2004, 50, 253-259. [CrossRef]

45. Minami, E.; Saka, S. Decomposition behavior of woody biomass in water-added supercritical methanol. J. Wood Sci. 2005, 51, 395-400. [CrossRef]

46. Varman, M.; Saka, S. A comparative study of oil palm and Japanese beech on their fractionation and characterization as treated by supercritical water. Waste Biomass Valor. 2011, 2, 309-315. [CrossRef]

47. Akalin, M.K.; Karagöz, S.; Akyüz, M. Supercritical ethanol extraction of bio-oils from German beech wood: Design of experiments. Ind. Crops Prod. 2013, 49, 720-729. [CrossRef]

48. Piqueras, C.M.; Cabeza, A.; Gallina, G.; Cantero, D.A.; Garcia-Serna, J.; Cocero, M.J. Online integrated fractionation-hydrolysis of lignocellulosic biomass using sub- and supercritical water. Chem. Eng. J. 2017, 308, 110-125. [CrossRef]

49. Chumpoo, J.; Prasassarakich, P. Bio-oil from hydro-liquefaction of bagasse in supercritical ethanol. Energy Fuels 2014, 24, 2071-2077. [CrossRef]

50. Demirbaş, A. Hydrogen production from biomass via supercritical water extraction. Energy Sources 2005, 27, 1409-1417. [CrossRef]

51. Knez, Ž.; Hrnčič, M.K.; Čolnik, M.; Škerget, M. Chemicals and value added compounds from biomass using sub- and supercritical water. J. Supercrit. Fluids 2018, 133, 591-602. [CrossRef] 
52. Cocero, M.J.; Cabeza, A.; Abad, N.; Adamovic, T.; Vaquerizo, L.; Martinez, C.M.; Pazo-Cepeda, M.V. Understanding biomass fractionation in subcritical and supercritical water. J Supercrit. Fluids 2018, 133, 550-565. [CrossRef]

53. Lin, M.-C.; Tsai, M.-J.; Wen, K.-C. Supercritical fluid extraction of flavonoids from Scutellariae radix. J. Chromatogr. A 1999, 830, 387-395. [CrossRef]

54. Liu, J.; Lin, S.; Wang, Z.; Wang, C.; Wang, E.; Zhang, Y.; Liu, J. Supercritical fluid extraction of flavonoids from Matdis stigma and its nitrite-scavenging ability. Food Bioprod. Process. 2011, 89, 333-339. [CrossRef]

55. Chiu, K.-L.; Cheng, Y.-C.; Chen, J.-H.; Chang, C.J.; Yang, P.-W. Supercritical fluids extraction of Ginkgo ginkgolides and flavonoids. J. Supercrit. Fluids 2002, 24, 77-87. [CrossRef]

56. Sun, M.; Temelli, F. Supercritical carbon dioxide extraction of carotenoids from carrot using canola oil as a continuous co-solvent. J. Supercrit. Fluids 2006, 37, 397-408. [CrossRef]

57. Filho, G.L.; De Rosso, V.V.; Meireles, M.A.; Rosa, P.T.V.; Oliveira, A.I.; Mercadante, A.Z.; Cabral, F.A. Supercritical $\mathrm{CO}_{2}$ extraction of carotenoids from pitanga fruits (Eugenia uniflora L.). J. Supercrit. Fluids 2008, 46, 33-39. [CrossRef]

58. Vagi, E.; Simandi, B.; Vasarhelyine, K.P.; Daood, H.; Kery, A.; Doleschall, F.; Nagy, B. Supercritical carbon dioxide extraction of carotenoids, tocopherols, and sitosterols from industrial tomato by-products. J. Supercrit. Fluids 2007, 40, 218-226. [CrossRef]

59. Botelho, J.R.; Medeiros, N.G.; Rodrigues, A.M.C.; Araujo, M.E.; Machado, N.T.; Santos, A.G.; Santos, I.R.; Gomes-Leal, W.; Carvalho, R.N., Jr. Black sesame (Sesamum indicum L.) seeds extracts by $\mathrm{CO}_{2}$ supercritical fluid extraction: Isotherms of global yield, kinetic data, total fatty acids, phytosterols and neuroprotective effects. J. Supercrit. Fluids 2014, 93, 49-55.

60. Bogdanovic, A.; Tadic, V.; Stamenuc, M.; Petrovic, S.; Skala, D. Supercritical carbon dioxide extraction of Trigonella foenium-graecum L. seeds: Process optimization using response surface methodology. J. Supercrit. Fluids 2016, 107, 44-50. [CrossRef]

61. Oba, C.; Ota, M.; Nomura, K.; Fujiwara, H.; Takito, J.; Sato, Y.; Ohizumi, Y.; Inomata, H. Extraction of nobiletin from Citrus Unshiu peels by supercritical fluid and its CRE-mediated transcriptional activity. Phytomedicine 2017, 27, 33-38. [CrossRef]

62. Roseiro, L.B.; Duarte, L.C.; Oliveira, D.L.; Roque, R.; Bernardo-Gil, M.G.; Martins, A.I.; Sepulveda, C.; Almeida, J.; Meireles, M.; Girio, F.M.; et al. Supercritical ultrasound and conventional extracts from carob (Ceratonia silique L.) biomass: Effect on phenolic profile and antiproliferative activity. Ind. Crops Prod. 2011, 47, 132-138. [CrossRef]

63. Santos, E.R.M.; Oliveira, H.N.M.; Oliveira, E.J.; Azevedo, S.A.G.; Jesus, A.A.; Medeiros, A.M.; Dariva, C.; Sousa, E.M.B.D. Supercritical fluyid extraction of Rumex Acetosa L. roots: Yield, composition, kinetics, bioactive evaluation and comparison with conventional techniques. J. Supercrit. Fluids 2017, 122, 1-9. [CrossRef]

64. Wajs-Bonikowska, A.; Stobiecka, A.; Bonikowski, R.; Krajewska, A.; Sikora, M.; Kula, J. A comparative study on composition and antioxidant activities of supercritical carbon dioxide, hexane and ethanol extracts from blackberry (Rubus fruticosus) growing in Poland. J. Sci. Food Agric. 2017, 97, 3576-3583. [CrossRef]

65. Marques, L.L.M.; Panizzon, G.P.; Aguiar, B.A.A.; Simionato, A.S.; Cardozo-Filho, L.; Andrade, G.; Oliviera, A.G.; Guedes, Y.A.; Mello, J.C.P. Guarana (Paullinia cupana) seeds: Slective supercritical extraction of phenolic compounds. Food Chem. 2016, 212, 703-711. [CrossRef]

66. Bendif, H.; Miara, M.D.; Kalboussi, Z.; Grauzdyte, D.; Povilaitis, D.; Venskutoniz, P.R.; Maggi, F. Supercritical $\mathrm{CO}_{2}$ extraction of Rosmarinus eriocalyx growing in Algeria: Chemical composition and antioxidant activity of extracts and their solid plant meterials. Ind. Crops Prod. 2018, 111, 768-774. [CrossRef]

67. Schaeffer, S.T.; Zalkov, L.H.; Taja, A.S. Modelling of supercritical fluid extraction of monocrotaline from Crotalaria Spectabilis. J. Supercrit. Fluids 1989, 2, 15-21. [CrossRef]

68. Demirbas, A. Hydrogen-rich gas from fruit shells via supercritical water extraction. Int. J. Hydrogen Technol. 2004, 29, 1237-1243. [CrossRef]

69. Aysu, T.; Turhan, M.; Kicuk, M.M. Liquefaction of Typha latifolia by supercritical fluid extraction. Bioresource Technol. 2012, 107, 464-470. [CrossRef]

70. Durak, H.; Aysu, Y. Effects of catalysts and solvents on liquefaction of Onopordum heteracanthum for production of bio-oils. Bioresource Technol. 2014, 166, 309-317. [CrossRef] 
71. Caputo, G.; Rubio, P.; Scargiali, F.; Marotta, G.; Brucato, A. Experimental and fluid dynamic study of continuous supercritical water gasification of glucose. J. Supercrit. Fluids 2016, 107, 450-461. [CrossRef]

72. Tekin, K.; Akalin, M.K.; Karagöz, S. Experimental design for extraction of bio-oils from flax seeds under supercritical ethanol conditions. Clean Technol. Environ. Policy 2016, 18, 461-471. [CrossRef]

73. Patil, P.D.; Gude, V.G.; Mannarswamy, A.; Deng, S.; Cooke, P.; Munson-McGee, S.; Rhodes, I.; Lammers, P.; Nirmalakhandan, N. Optimization of direct conversion of wet algae to biodiesel under supercritical methanol conditions. Bioresource Technol. 2011, 102, 118-122. [CrossRef]

74. Patil, P.D.; Gude, V.G.; Mannarswamy, A.; Cooke, P.; Nirmalakhandan, N.; Lammers, P.; Deng, S. Comparison of direct transesterification of algal biomass under supercritical methanol and microwave irradiation conditions. Fuel 2012, 97, 822-831. [CrossRef]

75. Patil, P.D.; Reddy, H.; Muppaneni, T.; Schaub, T.; Holguin, F.O.; Cooke, P.I.; Lammers, P.; Nirmalakhandan, N.; Li, Y.; Lu, X.; et al. In situ ethyl ester production from wet algae biomass under microwave-mediated supercritical ethanol conditions. Bioresource Technol. 2013, 139, 308-315. [CrossRef]

76. Caputo, G.; Dispenza, M.; Rubio, P.; Scargiali, F.; Marotta, G.; Brucato, A. Supercritical water gasification pf microalgae and their constituents in a continuous reactor. J. Supercrit. Fluids 2016, 118, 163-170. [CrossRef]

77. $\mathrm{Xu}, \mathrm{D}$.; Savage, P.E. Supercritical water upgrading of water-insoluble and water-soluble biocrudes from hydrothermal liquefaction of Nannochloropsis microalgae. J. Supercrit. Fluids 2018, 133, 683-689. [CrossRef]

78. McKennedy, J.; Önenc, S.; Pala, M.; Maguire, J. Supercritical carbon dioxide treatment of the microalgae Nannochloropsis oculata for the production of fatty acid methyl esters. J. Supercrit. Fluids 2016, 116, 264-270. [CrossRef]

79. Sivagnanam, S.P.; Yin, S.; Choi, J.; Park, Y.B.; Woo, H.C.; Chun, B.S. Biological properties of fucoxanthin in oil recovered from two brown seaweeds using supercritical carbon dioxide extraction. Mar. Drugs 2015, 13, 3422-3442. [CrossRef]

80. Ospina, M.; Castro-Vargas, H.L.; Parada-Alfonso, F. Antioxidant capacity of Colombian seaweeds. 1. Extracts obtained from Gracilaria mammillaris by means of supercritical fluid extraction. J. Supercrit. Fluids 2017, 128, 314-322. [CrossRef]

81. DeMarco, I.; Riemma, S.; Iannone, R. Life cycle assessment of supercritical $\mathrm{CO}_{2}$ extraction of caffeine from coffee beans. J. Supercrit. Fluids 2018, 133, 393-400. [CrossRef]

82. Lee, S.; Park, M.K.; Kim, K.H.; Kim, Y.-S. Effect of supercritical carbon dioxide decaffeination on volatile components of green teas. J. Food Sci. 2007, 72, S497-S501. [CrossRef]

83. Park, H.S.; Kim, N.G.; Kim, K.H. Extraction behaviors of caffeine and chlorophylls in supercritical decaffeination of green tea leaves. LWT Food Sci. Technol. 2012, 45, 73-78. [CrossRef]

84. Park, H.S.; Lee, H.J.; Shin, M.H.; Lee, K.-W.; Lee, H.; Kim, Y.-S.; Kim, K.O.; Kim, K.H. Effects of cosolvents on the decaffeination of green tea by supercritical carbon dioxide. Food Chem. 2007, 105, 1011-1017. [CrossRef]

85. Sun, Q.-L.; Hua, S.; Ye, J.-H.; Lu, J.-L.; Zheng, X.-Q.; Liang, Y.-R. Decaffeination of green tea by supercritical carbon dioxide. J. Med. Plants Res. 2010, 4, 1161-1168.

86. Bahar, B.; Pelvan, E.; Hasbay, I.; Alasalvar, C. Decaffeinated black tea: Process optimization and phenolic profiles. J. Supercrit. Fluids 2013, 82, 116-121. [CrossRef]

87. Joshi, R.; Babu, K.; Gulati, A. Effect of decaffeination conditions on quality parameters of Kangra orthodox black tea. Food Res. Int. 2013, 53, 693-703. [CrossRef]

88. Ilgaz, S.; Sat, I.G.; Polat, A. Effects of processing parameters on the caffeine extraction yield during decaffeination of black tea using pilot-scale supercritical carbon dioxide extraction technique. J. Food Sci. Technol. 2018, 55, 1407-1415. [CrossRef] [PubMed]

89. Kobori, K.; Maruta, Y.; Mineo, S.; Shigematsu, T.; Hirayama, M. Polyphenol-retaining decaffeinated cocoa powder obtained by supercritical carbon dioxide extraction and its antioxidant activity. Foods 2013, 2, 462-477. [CrossRef] [PubMed]

90. Perrut, M. Sterilization and virus deactivation by supercritical fluids (a review). J. Supercrit. Fluids 2012, 66, 359-371. [CrossRef]

91. Silva, J.M.; Rigo, A.A.; Dalmolin, I.A.; Debien, I.; Cansian, R.L.; Oliviera, J.V.; Mazutti, M.A. Effect of pressure, depressurization rate and pressure cycling on the inactivation of Escheria coli by supercritical carbon dioxide. Food Control 2013, 29, 76-99. [CrossRef] 
92. Park, H.S.; Lee, Y.H.; Kim, W.; Choi, H.-J.; Kim, K.-H. Disinfection of wheat grains contaminated with Penicillium oxalicum spores by supercritical carbon dioxide-water cosolvent system. Int. J. Food Microbiol. 2012, 150, 239-244. [CrossRef]

93. Park, H.S.; Choi, H.J.; Kim, K.H. Effect of supercritical $\mathrm{CO}_{2}$ modified with water cosolvent on the sterilization of fungal spore-contaminated barley seeds and the germination of barley seeds. J. Food Saf. 2013, 33, 94-101. [CrossRef]

94. Sikin, A.M.; Walkling-Ribeiro, M.; Rizvi, S.S.H. Synergistic effect of supercritical carbon dioxide and peracetic acid on microbial inactivation in shredded Mozarella-type cheese and its storage stability at ambient temperatures. Food Control 2016, 70, 174-182. [CrossRef]

95. Omar, A.K.M.; Norsalwani, T.L.T.; Abdul Khalil, H.P.S.; Nagao, H.; Zuknik, M.H.; Hossain, M.S.; Norulaini, N.A.N. Waterless sterilization of oil palm fruitlets using supercritical carbon dioxide. J. Supercrit. Fluids 2017, 126, 65-71. [CrossRef]

96. Omar, A.K.M.; Norsalwani, T.L.T.; Asmah, M.S.; Badrulhisham, Z.Y.; Easa, A.M.; Omar, F.M.; Hossain, M.S.; Zuknik, M.H.; Norulaini, N.A.N. Implementation of the supercritical carbon dioxide technology in oil palm fresh fruits bunch sterilization: A review. J. $\mathrm{CO}_{2}$ Utilization 2018, 25, 205-215. [CrossRef]

97. Marulanda, V.; Bolanos, G. Supercritical water oxidation of a heavily PCB-contaminated mineral transformer oil: Laboratory-scale data and economic assessment. J. Supercrit. Fluids 2010, 54, 258-265. [CrossRef]

98. Kim, K.; Kim, K.S.; Son, S.H.; Cho, J.; Kim, Y.-C. Supercritical water oxidation of transformer oil contaminated with PCBs-A road to commercial plant from bench-scale facility. J. Supercrit. Fluids 2011, 58, 121-130. [CrossRef]

99. Kronholm, J.; Kalpala, J.; Hartonen, K.; Riekkola, M.-J. Pressurized hot water extraction coupled with supercritical water oxidation in remediation of sand and soil containing PAHs. J. Supercrit. Fluids 2002, 23, 123-134. [CrossRef]

100. Kronholm, J.; Kuosmanen, T.; Hartonen, K.; Riekkola, M.-J. Destruction of PAHs from soil by using pressurized hot water extraction coupled with supercritical water oxidation. Waste Manag. 2003, 23, 253-260. [CrossRef]

101. Zhou, W.; Anitescu, G.; Rice, P.A.; Tavlarides, L.L. Supercritical fluid extraction-oxidation technology to remediate PCB-contaminated soils/ sediments: An economic analysis. Environ. Progr. 2004, 23, 222-231. [CrossRef]

102. Haglund, P. Methods for treating soils contaminated with polychlorinated dibenzo-p-dioxins, dibenzofurans, and other polychlorinated aromatic compounds. Ambio 2007, 36, 467-474. [CrossRef]

103. Subramanian, B.; Rajewski, R.A.; Snavely, K. Pharmaceutical processing with supercritical carbon dioxide. J. Pharmaceut. Sci. 1997, 86, 886-890.

104. Wakure, B.S.; Yadav, A.V.; Bhatia, N.M.; Salunke, M.A. Supercritical fluid technology: Nascent contrivance for pharmaceutical product development. Int. J. Pharmaceut. Sci. Res. 2012, 3, 1872-1882.

105. Esfandiari, N. Production of micro and nano particles of pharmaceuticals by supercritical carbon dioxide. J. Supercrit. Fluids 2015, 100, 129-141. [CrossRef]

106. Tenorio, A.; Gordillo, M.D.; Pereyra, C.M.; Martinez de la Ossa, E.J. Screening design of experiments applied to supercritical antisolvent precipitation of amoxicillin. J. Supercrit Fluids 2008, 44, 230-237. [CrossRef]

107. Tenorio, A.; Gordillo, M.D.; Pereyra, C.M.; Martinez de la Ossa, E.J. Supercritical antisolvent process applied to the pharmaceutical industry. Particulate Sci. Technol. 2010, 28, 262-266. [CrossRef]

108. Sui, X.; Wei, W.; Yang, L.; Zu, Y.; Zhao, C.; Zhang, L.; Yang, F.; Zhang, Z. Preparation, characterization and in vivo assessment of the bioavailability of glycyrrhizic acid microparticles by supercritical anti-solvent process. Int. J. Pharmaceut. 2012, 423, 471-479. [CrossRef]

109. Pathak, P.; Meziani, M.J.; Desai, T.; Sun, Y.-P. Nanosizing drug particles in supercritical fluid processing. J. Am. Chem. Soc. 2004, 126, 10842-10843. [CrossRef]

110. Tozuka, Y.; Miyazaki, Y.; Takeuchi, H. A combinatorial supercritical $\mathrm{CP}_{2}$ system for nanoparticle production of indomethacin. Int. J. Pharmaceut. 2010, 386, 243-248. [CrossRef]

111. Thakur, R.; Gupta, R.B. Formation of phenotoin nanoparticles using rapid expansion of supercritical solution with solid cosolvent (RESS-SC) process. Int. J. Pharmaceut. 2006, 308, 190-199. [CrossRef]

112. Türk, M.; Bolten, D. Formation of submicron poorly water-soluble drugs by rapid expansion of supercritical solution (RESS): Results for naproxen. J. Supercrit. Fluids 2010, 55, 778-785. [CrossRef] 
113. Pandfo, C.; Cabanasd, A.; Cuadra, I.A. Preparation of pharmaceutical co-crystals throu7gh sustainable processes using supercritical carbon dioxide: A review. RSC Adv. 2016, 6, 71134-71150. [CrossRef]

114. Türk, M.; Upper, G.; Hills, P. Formation of composite drug-polymer particles by co-precipitation during rapid expansion of supercritical fluids. J. Supercrit. Fluids 2006, 39, 253-263. [CrossRef]

115. Kang, Y.; Wu, J.; Yin, G.; Huang, Z.; Yao, Y.; Liao, X.; Chen, A.; Pu, X.; Liao, L. Preparation, characterization and in vitro cytotoxicity of indomethacin-loaded PLLA-PLGA microparticles using supercritical $\mathrm{CO}_{2}$ technique. Eur. J. Pharmaceut. Biopharmaceut. 2008, 70, 85-97. [CrossRef]

116. Kalantarian, P.; Haririan, I.; Najafabadi, A.R.; Shokrgozar, M.A.; Vatanara, A. Entrapment of 6-fluorouracil into PLGA matrices using supercritical antisolvent processes. J. Pharm. Pharmacol. 2011, 63, 500-506. [CrossRef]

117. Soares da Silva, M.; Viveiros, R.; Morgado, P.I.; Agular-Ricardo, A.; Correia, I.J.; Casimiro, T. Development of 2-(dimethylamino)ethyl methacrylate-based molecular recognition devices for controlled drug delivery using supercritical fluid technology. Int. J. Pharmaceut. 2011, 416, 61-68. [CrossRef]

118. Braga, M.E.M.; Yañez, F.; Alvarez-Lorenzo, C.; Concheiro, A.; Duarte, C.M.M.; Gil, M.H.; de Sousa, H.C. Improved drug loading/release capacities of commercial contact lenses obtained by supercritical fluid assisted molecular imprinting methods. J. Control. Release 2010, 148, e102-e104. [CrossRef]

119. Yañez, F.; Martikainen, L.; Braga, M.E.M.; Alvarez-Lorenzo, C.; Concheiro, A.; Duarte, C.M.M.; Gil, M.H.; de Sousa, H.C. Supercritical fluid-assisted preparation of imprinted contact lenses for drug delivery. Acta Biomater. 2011, 7, 1019-1030. [CrossRef]

120. Argemi, A.; Domingo, C.; de Sousa, A.R.S.; Duarte, C.M.M.; Garcia-Gonzalez, C.A.; Saurina, J. Characterization of new topical ketoprophen formulations prepared by drug entrapment in solid lipid matrices. J. Pharmaceut. Sci. 2011, 100, 4783-4789. [CrossRef]

121. Davies, O.R.; Lewis, A.L.; Whitaker, M.J.; Tai, H.; Shakesheff, K.M.; Howdle, S.M. Applications of supercritical $\mathrm{CO}_{2}$ in the fabrication of polymer systems for drug delivery and tissue engineering. Adv. Drug Deliv. Rev. 2008, 60, 373-387. [CrossRef]

122. Okamoto, H.; Danjo, K. Application of supercritical fluid to preparation of powders of high-molecular weight drugs for inhalation. Adv. Drug Deliv. Rev. 2008, 60, 433-446. [CrossRef]

123. Zosel, K.U.S. Patent 3806619 (1974), Praktische Anwendungen der Stofftrennung mit überkritischen Gasen. Angew. Chem. 1978, 90, 748-755. [CrossRef]

124. Gandhi, K.; Arora, S.; Kumar, A. Industrial applications of supercritical fluid extraction: A review. Int. J. Chem. Stud. 2017, 5, 336-340.

125. Prieto, C.; Calvo, L.; Duarte, C.M.M. Continuous supercritical fluid extraction of emulsions to produce nanocapsules of vitamin E in polycaprolactone. J. Supercriti. Fluids 2017, 124, 72-79. [CrossRef]

126. Abdul Khalil, H.P.S.; Lai, T.K.; Tye, Y.Y.; Rizal, S.; Chong, E.W.N.; Yap, S.W.; Hamzah, A.A.; Fazita, M.R.N.; Paridah, M.T. A review of extractions of seaweed hydrocolloids: Properties and applications. Express Polym. Lett. 2018, 12, 296-317. [CrossRef]

(c) 2019 by the author. Licensee MDPI, Basel, Switzerland. This article is an open access article distributed under the terms and conditions of the Creative Commons Attribution (CC BY) license (http://creativecommons.org/licenses/by/4.0/). 